International Journal of Instruction

e-ISSN: 1308-1470 • www.e-iji.net

Article submission code:

2020040201583

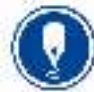

Received: 02/04/2020

Revision: 28/09/2020
April 2021 • Vol.14, No.2

p-ISSN: 1694-609X

pp. 483-500

Accepted: 21/10/2020

OnlineFirst: 26/01/2021

\title{
Big Five Personality Test for State Islamic Senior High School Students in Indonesia
}

\section{Abdul Muhid}

UIN Sunan Ampel Surabaya, Indonesia, abdulmuhid@uinsby.ac.id

Ali Ridho

UIN Maulana Malik Ibrahim Malang, Indonesia,aliridho@uin-malang.ac.id

\section{Ahmad Yusuf}

UIN Sunan Ampel Surabaya, Indonesia, ahmadyusuf@uinsby.ac.id

Noor Wahyudi

UIN Sunan Ampel Surabaya, Indonesia, n.wahyudi@uinsby.ac.id

\section{Zakiyatul Ulya}

UIN Sunan Ampel Surabaya, Indonesia, zakiyatululya@uinsby.ac.id

\section{Ahmad Hanif Asyhar}

UIN Sunan Ampel Surabaya, Indonesia, hanif@uinsby.ac.id

Personality is one of the important variables for predicting student academic success. The purpose of the research is to examine the Big Five personality test as a predictor on the academic achievement of State Islamic Senior High School students in Indonesia. This research used a quantitative method which used a survey of the Big Five Personality Test and learning achievement on 5 subjects. The subjects of this study were the 2145 sample students of 23 State Islamic Senior High School of Insan Cendekia (SISHS-IC) around Indonesia. The results of this study indicate that all dimensions of Big Five Personality traits; openness to experience, conscientiousness, extraversion, agreeableness, and emotional stability have a significant effect as predictors of students' academic achievement. While in parts of each dimension, the most significant predictor of students' academic achievement is the emotional stability and openness to experience. These findings are very important for teachers and schools to pay much more attention to emotional stability and openness to experience as predictors of student academic achievement.

Keywords: academic achievement, Big Five Personality, predictor, regression, test

\section{INTRODUCTION}

Student academic success is strongly influenced by internal and external factors (Hamid, 2019). The influence of internal factors such as student characteristics and personality is 
important determinants in predicting students' academic performance in the classroom (Ismail, Mahmood, and Abdelmaboud, 2018). Ciorbea and Pasarica (2013), stated that personality factors are variables that influence student academic performance. Similarly, according to Mihaela (2015), psychological factors such as personality are very influential in academic success. Therefore, this personality factor is a concern of education practitioners and researchers. One of the personal factor as a determinant of academic success is the personality factor.

Personality is one of the non-cognitive aspects that is often considered as a predictor of academic performance (Conard 2006). Likewise, personality is a fundamental aspect of human beings that influences academic performance (Vedel and Poropat, 2017). In addition, Entwistle (2018) stated that personality and motivational characteristics are significant predictors of academic performance. Some expert in education suggested paying attention to personality variables to determine student academic performance ( Shokri, Kadivar, Naghsh, Ghanai, Daneshvarpour, and Molaei, 2007). Similarly, Ramesh, Reddy, Rao, Dhandapani, Siva, and Ramakrishna (2017) explained that educators and researchers need to pay attention to personality variables in learning as a students' strength to improve academic performance. Lee and Stankov (2018) have confirmed that one of the non-cognitive variables used as ability predictors of the Third International Mathematics and Science Study (TIMSS) and students' Program for International Assessment of Students (PISA) is a personality type.

One of the personality approaches that can be used to reveal the personality aspects is the Big Five personality approach (De Raad and Mlačić, 2015). According to De Raad and Mlačić (2017), the Big Five personality approach is known as the structure of the personality model. The Big Five personality approach model has 5 personality structures; neuroticism, extraversion, openness, agreeableness and conscientiousness (McCrae and Costa Jr, 2008). The opposite pole of neuroticism denotes emotional stability (Goldberg 1990, 1992). As an example, Rosito (2018) found that the five dimensions of Big Five personality significantly influence student academic achievement. While, according to Bhagat, Shetty, Husain, Mat, Simbak, Aung, and Oo, (2019), concluded that personality is the combination of individual character as a capital for academic career success. In short, Big Five Personality is able to predict positively on academic achievement.

Among many kinds of research, the researchers found different effects of Big Five Personality as predictors of academic performance. As an example, Jensen's (2015) showed that openness to experience influenced student learning and general knowledge, while conscientiousness influenced academic achievement. Similarly, Raza and Shah's findings (2017) found that empirical evidence of all Big Five personality significantly influenced academic achievement, except agreeableness. Brandt, Lechner, Tetzner, Rammstedt (2019) stated that conscientiousness, openness, and emotional stability were the most significant predictors of academic performance. According to Demetriou, Kazi, Spanoudis, and Makris (2019), the most significant variable predictor is the conscientiousness. While, according to Novikova and Vorobyeva (2017), consciousness and openness are the highest predictions of academic achievement. Similarly, Sorić, 
Penezić, and Burić, (2017) stated that conscientiousness alone has not so significant on academic achievement. In contrast, Varadwaj (2017) found that the types of conscientiousness, agreeableness, and openness were the most significant predictor of academic achievement. Likewise, Köseoğlu (2016) stated that the types of conscientiousness and agreeableness are the most significant in predicting student academic achievement. Similarly, Kirkagac and Öz (2017) showed that the types of conscientiousness, openness and agreeableness significantly predict academic achievement.

However, in Indonesia, there are few studies, if any, which analyzed the prediction of Big Five personality for student academic achievement. The aim of this study is finding predictors of academic achievement based on students' personality. Thus, the results of this study are very useful as policymaker reference in the national new student selection programs. This research is critical as consideration for stakeholders in making decisions since it presents empirical findings of the prediction test of the five dimensions of the Big Five Personality; openness to experience, conscientiousness, extraversion, agreeableness, and emotional stability on academic achievement of State Islamic Senior High School of Insan Cendekia (SISHS-IC) around Indonesia. In addition, this study reveals a predictive level both simultaneously and partially each dimension of the Big Five Personality traits of the five main subjects in SISHS-IC; Islamic Studies, Arabic, English, science, and mathematics

\section{METHOD}

This research uses a quantitative approach with correlational causality design. The survey method is used to collect data by conducting learning achievement tests to participants. Learning achievement that collected in this study was students' grades obtained in the first semester.

The population of this study is 1.465 .445 students of Islamic Senior High School in Indonesia (Anon 2020). Quota sampling technique was used to select participants which resulted in 2145 students who were taken from 23 State Islamic Senior High School of Insan Cendekia (SISHS-IC) around Indonesia. Table 1 shows the distribution of participants. 
Table 1

Distribution of respondent

\begin{tabular}{lll}
\hline Demography & Frequency & Percentage \\
\hline Gender & 1036 & 48 \\
\hline Male & 1109 & 52 \\
\hline Name of Educational Institution & & \\
\hline SISHS-IC Aceh Timur & 96 & 4.5 \\
\hline SISHS-IC Bangka Tengah & 96 & 4.5 \\
\hline SISHS-IC Bengkulu Tengah & 89 & 4.1 \\
\hline SISHS-IC Gorontalo & 119 & 5.5 \\
\hline SISHS-IC Gowa & 72 & 3.3 \\
\hline SISHS-IC Halmahera Barat & 48 & 2.2 \\
\hline SISHS-IC Jambi & 120 & 5.6 \\
\hline SISHS-IC Batam & 96 & 4.5 \\
\hline SISHS-IC Kendari & 96 & 4.5 \\
\hline SISHS-IC Palu & 96 & 4.5 \\
\hline SISHS-IC Pekalongan & 93 & 4.3 \\
\hline SISHS-IC Lampung Timur & 48 & 2.2 \\
\hline SISHS-IC Lombok Timur & 72 & 3.3 \\
\hline SISHS-IC Ogan Komering Ilir & 96 & 4.5 \\
\hline SISHS-IC Padang Pariaman & 96 & 4.5 \\
\hline SISHS-IC Paser & 96 & 4.5 \\
\hline SISHS-IC Pasuruan & 96 & 4.5 \\
\hline SISHS-IC Sambas & 96 & 4.5 \\
\hline SISHS-IC Serpong & 140 & \\
\hline SISHS-IC Siak & 96 & 965 \\
\hline SISHS-IC Sorong & 96 & \\
\hline
\end{tabular}

\section{Instrument}

This study used a measuring instrument of achievement test / academic achievement of five subjects in SISHS-IC; Islamic Studies, Arabic, English, science, and mathematics. This academic/academic achievement test was developed by a team of national question compilers from the Directorate of Islamic school centre assessment at the Indonesian 
Ministry of Religion (MORA). While to measure the Big Five personality, it used the Big Five personality test which consisted of five dimensions: (1) openness to experience; (2) conscientiousness; (3) extraversion; (4) agreeableness; and (5) emotional stability. This test was also developed by the assessment expert centre team from the Islamic School Directorate at MORA.

\section{Data Analysis}

This research used multiple linear regression. The stepwise technique is used to analyze the effect of each dimension of the Big Five personality traits on student academic achievement. The data analysis entirely conducted by using IBM SPSS Version 25. Before multiple linear regression analysis is performed, the assumption test is checked by the data normality test, the relationship linearity test, the multicollinearity test, and the heteroscedasticity test. Based on the assumptions test results above show that the data in this study are all normally distributed, the relationship between the five predictor variables with the criterion variable is also linearly related to the five predictor variables avoiding multicollinearity, and the data in this study do not occur heteroscedasticity. Thus, this study can be used parametric statistical testing, namely multiple linear regression analysis to test the five predictor variables (Big Five personality with criterion variables (Academic Achievement).

\section{FINDINGS}

\section{Big Five Personality and Academic Achievement}

The result of statistical analysis in Table 2 shows that there are simultaneous influences on all dimensions of Big Five Personality; openness to experience, conscientiousness, extraversion, agreeableness, and emotional stability on SISHS-IC student academic achievement $\left(\mathrm{r}=.217 ; \mathrm{r}^{2}=.047 ; \mathrm{F}=21,069 ; \mathrm{P}=.000\right)$. In general, the five dimensions of Big Five Personality became a significant predictor variable on SISHS-IC student academic achievement.

Table 2

Multiple regression analysis of Big Five Personality Traits on Academic Achievement

\begin{tabular}{ll}
\hline Statistic & Value \\
\hline $\mathrm{F}$ & 21.069 \\
\hline $\mathrm{P}$ & .000 \\
\hline $\mathrm{r}$ & .217 \\
\hline $\mathrm{r}^{2}$ & .047 \\
\hline
\end{tabular}

Table 3 shows that the five dimensions of Big Five Personality; openness to experience, conscientiousness, extraversion, agreeableness, and emotional stability have different effects on SISHS-IC student academic achievement. The emotional stability, openness to experience and extraversion have a significant influence on the academic achievement of SISHS-IC students. While the conscientiousness and agreeableness do not have a significant impact on academic achievement of SISHS-IC students. The finding of this study also indicates that the emotional stability and openness to experience are the 
dimensions of Big Five Personality traits that have the most significant influence as predictors of academic achievement in SISHS-IC students. To conclude, SISHS-IC students who have emotional stability and openness to experience personality types have a tendency to have high academic achievement

Table 3

The influence of each dimension big five personality traits on academic achievement

\begin{tabular}{llll}
\hline Personality Dimensions & $\mathrm{B}$ & $\mathrm{T}$ & $\mathrm{P}$ \\
\hline Openness to experience & 5.177 & 6.819 & .000 \\
\hline Conscientiousness & .810 & .952 & .341 \\
\hline Extraversion & -1.682 & -2.020 & .043 \\
\hline Agreeableness & -1.370 & -1.359 & .124 \\
\hline Emotional stability & 4.904 & 6.256 & .000 \\
\hline
\end{tabular}

Based on table 3, it can be arranged with linear regression equations in this study are as follows:

$$
\begin{aligned}
\mathrm{Y}^{\prime} & =\mathrm{a}+\mathrm{b}_{1} \mathrm{X}_{1}+\mathrm{b}_{2} \mathrm{X}_{2}+\mathrm{b}_{3} \mathrm{X}_{3}+\mathrm{b}_{4} \mathrm{X}_{4}+\mathrm{b}_{5} \mathrm{X}_{5} \\
\mathrm{Y}^{\prime} & =2287.278+5.177 \mathrm{X}_{1}+.810 \mathrm{X}_{2}+(-1.682) \mathrm{X}_{3}+(-1.370) \mathrm{X}_{4}+4.904 \mathrm{X}_{5} \\
\mathrm{Y}^{\prime} & =2287.278+5.177+.810-1.682-1.370+4.904
\end{aligned}
$$

Symbol Description

$$
\begin{aligned}
& \mathrm{Y}^{\prime}=\text { Academic Achievement } \\
& \mathrm{a} \quad=\text { constant } \\
& \mathrm{b}_{1}, \mathrm{~b}_{2}, \mathrm{~b}_{3}, \mathrm{~b}_{4}, \mathrm{~b}_{5}=\text { regression coefficient } \\
& \mathrm{X}_{1} \quad=\text { Openness to experience } \\
& \mathrm{X}_{2} \quad=\text { Conscientiousness } \\
& \mathrm{X}_{3} \quad=\text { Extraversion } \\
& \mathrm{X}_{4} \quad=\text { Agreeableness } \\
& \mathrm{X}_{5} \quad=\text { Emotional Stability }
\end{aligned}
$$

Based on the regression equation can be explained as follows: (1) a constant of 2287,278 , meaning that if Openness to experience $\left(X_{1}\right)$, Conscientiousness $\left(X_{2}\right)$, Extraversion $\left(\mathrm{X}_{3}\right)$, Agreeableness $\left(\mathrm{X}_{4}\right)$, Emotional Stability $\left(\mathrm{X}_{5}\right)$ the value is 0 , then Academic Achievement score ( $\left.\mathrm{Y}^{\prime}\right)$ the value is 2287,278 ; (2) the Openness to experience $\left(\mathrm{X}_{1}\right)$ regression coefficient is 5,177, meaning that if other predictor variables are fixed and the value of Openness to experience has increased 1, then the Academic Achievement score has increased by 5,177 ; (3) Conscientiousness $\left(\mathrm{X}_{2}\right)$ regression coefficient of .810 , meaning that if other predictor variables are fixed and the Conscientiousness value increases 1, the Academic Achievement score increases by .810; (4) Extraversion $\left(\mathrm{X}_{3}\right)$ regression coefficient of $-1,682$, meaning that if the other predictor variables are fixed and the value of Extraversion has increased by 1, then the 
Academic Achievement score has decreased by 1,682; (5) Agreeableness regression coefficient $\left(\mathrm{X}_{4}\right)$ of -1.370 , meaning that if other predictor variables are fixed and the value of Agreeableness has increased by 1, then the Academic Achievement score has decreased by 1,$370 ;(6)$ the Emotional Stability $\left(X_{5}\right)$ regression coefficient of 4.904, meaning that if other predictor variables are fixed and the Emotional Stability value increases 1, then the Academic Achievement score has increased by 4,904.

\section{Big Five Personality and Islamic Studies Subject}

Table 4 shows that there are simultaneous influences on all dimensions of Big Five Personality; openness to experience, conscientiousness, extraversion, agreeableness, and emotional stability on the achievement of Islamic Studies subjects $\left(r=.129 ; \mathrm{r}^{2}=.017 ; \mathrm{F}\right.$ $=7.294 ; \mathrm{P}=.000)$. In short, the five dimensions of Big Five Personality traits as a significant predictor variable on the achievement of Islamic Studies subjects

Table 4

Multiple regression analysis of big five personality traits on islamic studies achievement

\begin{tabular}{ll}
\hline Statistic & Value \\
\hline $\mathrm{F}$ & 7.294 \\
\hline $\mathrm{P}$ & .000 \\
$\mathrm{r}$ & .129 \\
\hline $\mathrm{r}^{2}$ & .017 \\
\hline
\end{tabular}

Table 5 shows that the five dimensions of Big Five Personality; openness to experience, conscientiousness, extraversion, agreeableness, and emotional stability have different effects on the achievement of Islamic Studies subjects. The openness to experience, emotional stability, extraversion, and agreeableness have a significant influence on the achievement of Islamic Studies subjects. Whereas, only the conscientiousness does not have a significant effect on the achievement of Islamic Studies subjects. The finding of this study also shows that the openness to experience and emotional stability are the most significant predictors of Islamic Studies subject achievement. To sum up, the SISHS-IC students who have the personality type of openness to experience and emotional stability are supposed to have high achievements in Islamic Studies subjects.

Table 5

The influence of each dimension big five personality traits on academic achievement

\begin{tabular}{llll}
\hline Personality Dimensions & $\mathrm{B}$ & $\mathrm{T}$ & $\mathrm{P}$ \\
\hline Openness to experience & .904 & 4.162 & .000 \\
\hline Conscientiousness & .300 & 1.230 & .219 \\
\hline Extraversion & -.516 & -2.165 & .030 \\
\hline Agreeableness & -.512 & -2.009 & .045 \\
\hline Emotional stability & .701 & 3.126 & .002 \\
\hline
\end{tabular}

\section{Big Five Personality and Arabic Subject}

Table 6 shows that there are simultaneous influences on all dimensions of Big Five Personality traits, namely openness to experience, conscientiousness, extraversion, agreeableness, and emotional stability on the achievement of Arabic subjects ( $r=.129$; 
$\mathrm{r}^{2}=.017 ; \mathrm{F}=7.215 ; \mathrm{P}=.000$ ). In general, the five dimensions of Big Five Personality traits as a significant predictor variable on the achievement of Arabic subjects.

Table 6

Multiple regression analysis of big five personality traits on arabic achievement

\begin{tabular}{ll}
\hline Statistic & Value \\
\hline $\mathrm{F}$ & 7.215 \\
\hline $\mathrm{P}$ & .000 \\
\hline $\mathrm{r}$ & .129 \\
\hline $\mathrm{r}^{2}$ & .017 \\
\hline
\end{tabular}

Table 7 shows that the five dimensions of Big Five Personality; openness to experience, conscientiousness, extraversion, agreeableness, and emotional stability have different effects on the achievement of Arabic subjects. Dimensions of emotional stability, conscientiousness, extraversion, and agreeableness have a significant influence on the achievement of Arabic subjects. Another hand, the openness to experience has no significant effect on the achievement of Arabic subjects. The finding of this study also indicates that the dimensions of emotional stability and conscientiousness are the most significant predictors of Arabic subject achievement. In conclusion, in general, SISHSIC students who have emotional stability and conscientiousness personality types be likely to have high achievements in Arabic subjects.

Table 7

The influence of each dimension big five personality traits on academic achievement

\begin{tabular}{llll}
\hline Personality Dimensions & $\mathrm{B}$ & $\mathrm{T}$ & $\mathrm{P}$ \\
\hline Openness to experience & -.002 & -.005 & .996 \\
\hline Conscientiousness & 1.098 & 3.271 & .001 \\
\hline Extraversion & -.280 & -.852 & .027 \\
\hline Agreeableness & -.268 & -.764 & .040 \\
\hline Emotional stability & 1.137 & 3.674 & .000 \\
\hline
\end{tabular}

\section{Big Five Personality and English Subject}

Table 8 shows that there are simultaneous influences on all dimensions of Big Five Personality; openness to experience, conscientiousness, extraversion, agreeableness, and emotional stability on the achievement of English subjects $(\mathrm{r}=.177 ; \mathrm{r} 2=.029 ; \mathrm{F}=$ 13.828; $\mathrm{P}=.000$ ). In general, the five dimensions of Big Five Personality traits are the most significant predictors on the achievement of English subjects

Table 8

Multiple regression analysis of big five personality traits on english achievement

\begin{tabular}{ll}
\hline Statistic & Value \\
\hline $\mathrm{F}$ & 13.828 \\
\hline $\mathrm{P}$ & .000 \\
\hline $\mathrm{r}$ & .177 \\
\hline $\mathrm{r}^{2}$ & .029 \\
\hline
\end{tabular}

Table 9 shows that the five dimensions of Big Five Personality; openness to experience, conscientiousness, extraversion, agreeableness, and emotional stability have different 
effects on the achievement of English subjects. The dimensions of openness to experience, emotional stability, and conscientiousness have a significant influence on the achievement of English subjects. Whereas the dimensions of agreeableness and extraversion do not have a significant effect on the achievement of English subjects. The finding of this study also reveals that the openness to experience and emotional stability are the dimensions of Big Five Personality traits the most significant predictors on English subject achievement. In short, SISHS-IC students who have the type of personality openness to experience and emotional stability are supposed to have high achievement in English subjects

Table 9

The influence of each dimension big five personality traits on academic achievement

\begin{tabular}{llll}
\hline Personality Dimensions & $\mathrm{B}$ & $\mathrm{T}$ & $\mathrm{P}$ \\
\hline Openness to experience & 1.531 & 7.187 & .000 \\
\hline Conscientiousness & -.706 & -2.958 & .003 \\
\hline Extraversion & -.312 & -1.337 & .181 \\
\hline Agreeableness & -.021 & -.085 & .932 \\
\hline Emotional stability & .871 & 3.960 & .000 \\
\hline
\end{tabular}

Big Five Personality and Science Subject

Table 10 shows that there are simultaneous influences on all dimensions of Big Five Personality; openness to experience, conscientiousness, extraversion, agreeableness, and emotional stability on the achievement of science subjects $(\mathrm{r}=.184 ; \mathrm{r} 2=.034 ; \mathrm{F}=$ 15.016; $\mathrm{P}=15.016 ; \mathrm{P}=15.016 ; .000)$. In conclusion, the five dimensions of Big Five Personality traits are the most significant predictors on the achievement of science subjects.

Table 10

Multiple regression analysis of big five personality traits on science achievement

\begin{tabular}{ll}
\hline Statistic & Value \\
\hline $\mathrm{F}$ & 15.016 \\
\hline $\mathrm{P}$ & .000 \\
\hline $\mathrm{r}$ & .184 \\
\hline $\mathrm{r}^{2}$ & .034 \\
\hline
\end{tabular}

Table 11 shows that the five dimensions of Big Five Personality; openness to experience, conscientiousness, extraversion, agreeableness, and emotional stability have different effects on the achievement of science subjects. While the dimensions of openness to experience and emotional stability have a significant influence on the achievement of science subjects, the dimensions of agreeableness, conscientiousness and extraversion do not have a significant influence on the achievement of science subjects. The finding of this study also indicates that the dimensions of openness to experience and emotional stability are the most significant predictors of achievement in science subjects. In summary, SISHS-IC students who have the type of personality openness to experience and emotional stability have a tendency to have high achievements in science subjects. 
Table 11

The influence of each dimension big five personality traits on academic achievement

\begin{tabular}{llll}
\hline Personality Dimensions & $\mathrm{B}$ & $\mathrm{T}$ & $\mathrm{P}$ \\
\hline Openness to experience & 1.664 & 7.055 & .000 \\
\hline Conscientiousness & -.199 & -.752 & .452 \\
\hline Extraversion & -.362 & -1.399 & .162 \\
\hline Agreeableness & -.191 & -.689 & .491 \\
\hline Emotional stability & 1.063 & 4.055 & .000 \\
\hline
\end{tabular}

\section{Big Five Personality and Mathematics Subject}

Table 12 shows that there are simultaneous influences on all dimensions of Big Five Personality; openness to experience, conscientiousness, extraversion, agreeableness, and emotional stability on the achievement of mathematics subjects $(\mathrm{r}=.170 ; \mathrm{r} 2=.029 ; \mathrm{F}=$ $12.749 ; \mathrm{P}=12.749 ; .000)$. In conclusion, the five dimensions of Big Five Personality traits as a significant predictor variable on the achievement of mathematics subjects.

Table 12

Multiple regression analysis of big five personality traits on mathematics achievement

\begin{tabular}{ll}
\hline Statistic & Value \\
\hline $\mathrm{F}$ & 12.749 \\
\hline $\mathrm{P}$ & .000 \\
\hline $\mathrm{r}$ & .170 \\
\hline $\mathrm{r}^{2}$ & .029 \\
\hline
\end{tabular}

Table 13 shows that the five dimensions of Big Five Personality; openness to experience, conscientiousness, extraversion, agreeableness, and emotional stability have different effects on the achievement of mathematics subjects. The dimensions of emotional stability and openness to experience alone have a significant influence on the achievement of mathematics subjects, while the dimensions of extraversion, agreeableness and conscientiousness do not have a significant influence on the achievement of mathematics subjects. The finding of this study also indicates that the dimensions of emotional stability and openness to experience are the most significant predictors of mathematics subject achievement. To conclude, SISHS-IC students who have emotional stability and openness to experience personality types be likely to have high achievement in mathematics.

Table 13

The influence of each dimension big five personality traits on academic achievement

\begin{tabular}{llll}
\hline Personality Dimensions & $\mathrm{B}$ & $\mathrm{T}$ & $\mathrm{P}$ \\
\hline Openness to experience & 1.079 & 4.794 & .000 \\
\hline Conscientiousness & .318 & 1.259 & .208 \\
\hline Extraversion & -.214 & -.868 & .386 \\
\hline Agreeableness & -.378 & -1.432 & .152 \\
\hline Emotional stability & 1.133 & 4.875 & .000 \\
\hline
\end{tabular}




\section{DISCUSSION}

The result of this study proves that all dimensions of Big Five Personality; openness to experience, conscientiousness, extraversion, agreeableness, and emotional stability together have a significant effect as predictors of SISHS-IC student academic achievement. The result of this study confirms the findings of previous studies such as Lounsbury, Sundstrom, Loveland, and Gibson (2003); Loveland (2004); Ridgell and Lounsbury (2004); Leeson, Ciarrochi, and Heaven (2008); Furnham, Monsen, and Ahmetoglu (2009); Wang, Wang, and Dai (2011); Dzulkifli and Alias (2012); Galleher, Rundquist, Barker, and Chang (2012); Moldasheva and Mahmood (2014); Cazan and Schiopca (2014); Novikova and Vorobyeva, (2017) which stated that Big Five Personality traits are a significant predictor toward student academic achievement.

This study empirically finds evidence that among the five dimensions of Big Five Personality dimensions, the most significant predictor of achievement in all subjects (Islamic Studies, Arabic, English, science, and mathematics) is emotional stability dimension. In other words, this study confirms that students who have emotional and personal stability types are supposed to have high achievement in all subjects. This study confirms the findings of Kalita (2016) which stated that high school students who have high academic achievement are students who have high emotional stability. Likewise, Brandt, Lechner, Tetzner, Rammstedt (2019) showed that the type of emotional stability personality influences mathematics academic achievement. In the same way, Pulido-Acosta, and Herrera-Clavero (2019) assumed that emotional variables such as emotional intelligence are strong predictors of student academic achievement. In addition, Zahed-Babelan and Moenikia (2010); Chandramohan (2015); Razia and Ahmad (2017); Kotomina (2017); Leighton, Guo, Chu, and Tang (2018) stated that aspects of emotional intelligence are predictors of academic achievement. Likewise, Kashy-Rosenbaum, Kaplan, and Israel-Cohen (2018) claimed that the emotional level of students is a predictor of student academic achievement.

In the same way, the openness to experience is the most significant predictor in all subjects, except Arabic subjects. This result is in accordance with the previous studies which stated that openness to experience is a significant predictor of academic achievement. Students who have an openness to experience personality type have a tendency to have good academic performance (Morales-Vives, Camps, and Dueñas, 2020). Similarly, Paunonen, and Ashton (2001); Gilles and Bailleux (2001); Komarraju and Karau (2005); O'Connor and Paunonen (2007); Noftle and Robins (2007); Beaujean, Firmin, Attai, Johnson, Firmin, and Mena (2011); Lim, and Melissa Ng Abdullah (2012); Anghel (2015); Novikova and Vorobyeva (2017); Varadwaj (2017); Kirkagac and Öz (2017); Gatzka and Hell (2018) have found that personality openness to experience is a significant predictor to determine academic achievement. In addition, Kholin, Meurs, Blickle, Wihler, Ewen, and Momm (2016) stated that students who have the potential for openness to experience personality would be successful in learning and academic performance. Meanwhile, Tan, Lau, Kung, and Kailsan (2019) said that students who have the personality type of openness to experience seemed to have intrinsic motivation which impacts the process of creativity and academic achievement. 
In addition, the interesting finding in this research is that conscientiousness does not have a significant effect on student academic achievement. On the other hand, the finding of this study indicates that the conscientiousness cannot be a predictor in Islamic Studies, science, and mathematics subject. This finding supports Sorić, Penezić, and Burić, (2017)) which stated that the conscientiousness does not have a significant effect on academic achievement. However, conscientiousness is a significant predictor in Arabic and English subjects. Similarly, Molaei (2016) found that the conscientiousness is very influential on the effectiveness of the ELTIS (English Language Teaching Institute) program. Likewise, Erfani and Mardan (2017) confirmed that conscientiousness is related to English language proficiency scores on IELTS, and academic success of Iranian foreign students. Dinius (2013) found that conscientiousness influences students' perceptions of English as a second/foreign language (ESL / EFL) programs.

On the other hand, Meyer, Fleckenstein, Retelsdorf, and Köller (2019) stated that conscientiousness could predict the results of mathematics test scores and English achievement scores are significantly predicted by the openness to experience. However, previous studies such as Paunonen, and Ashton (2001); Furnham, Chamorro-Premuzic, and McDougall (2003); Duff, Boyle, Dunleavy, and Ferguson (2004); O'Connor and Paunonen (2007); Wang, Wang, and Dai (2011); Komarraju, Karau, Schmeck, and Avdic (2011); Hakimi, Hejazi, and Lavasani (2011); Beaujean, Firmin, Attai, Johnson, Firmin, and Mena (2011); Zupančič and Kavčič (2011); Lim, and Melissa Ng Abdullah (2012); Lee and Chae (2013); Nighute and Sadawarte (2014); Köseoğlu (2016); Novikova and Vorobyeva (2017); Varadwaj (2017); Kirkagac and Öz (2017); Raza and Shah (2017); Demetriou, Kazi, Spanoudis, and Makris (2019); Morales-Vives, Camps, and Dueñas (2020) found empirical evidence that among the five Big Five Personality, the most significant predictor of academic achievement is conscientiousness.

Similarly, the agreeableness and extraversion personality types in this study do not have a significant influence on students' academic achievement. This means that agreeableness and extraversion personality types cannot be used as a predictor of student academic achievement. In other words, agreeableness and extraversion are not an effective dimension in predicting English, science and mathematics subjects. This finding supports Raza and Shah's research (2017) which showed that agreeableness is not a significant predictor of academic achievement. Similarly, O'Connor and Paunonen (2007) stated that extraversion negatively influences academic achievement. The agreeableness and extraversion function as predictor variables only in Islamic Studies and Arabic subjects. This study is in accordance with Ghazi, Shahzada, and Ullah (2013) which stated that the agreeableness personality type is related to the achievements of Islamic studies, including Arabic. Even though, Komarraju, Karau, Schmeck, and Avdic (2011); Nighute and Sadawarte (2014); Köseoğlu (2016); Kirkagac and Öz (2017); Varadwaj (2017) found that agreeableness is a significant predictor of academic achievement. 


\section{CONCLUSION}

Based on the explanation above, it can be concluded that all dimensions of Big Five Personality; openness to experience, conscientiousness, extraversion, agreeableness, and emotional stability are a significant predictor of academic achievement of SISHS-IC students around Indonesia. While partially, among the Big Five Personality that is the most significant predictor of student academic achievement is the emotional stability and openness to experience. In other word, students who have good emotional stability and openness to experience are supposed to have high academic achievement in all subjects. Furthermore, conscientiousness is an effective predictor only in Arabic and English subjects, while the agreeableness and extraversion are significant predictors in Islamic Studies and Arabic. The findings of this study are very important for teachers, especially for school to pay much more attention to the personality type of emotional stability and openness to experience as predictors of student academic achievement. Further research might analyze other personality traits that can be predictors for student achievement.

\section{ACKNOWLEDGMENT}

We thank the Ministry of Religious Affair especially Directorate of Curriculum, Facilities, Institutional and Students of Madrasah that supported data for this research.

\section{REFERENCE}

Anghel, Ramona Elena. 2015. "Predictors of Academic Performance among At-Risk Romanian Youth.” Revista Românească Pentru Educaţie Multidimensională 7(1), 18192.

Anon. 2020. "EMIS Ministry of Religious Affair of Republic of Indonesia." Retrieved June 24, 2020 (http://emispendis.kemenag.go.id/dashboard/).

Beaujean, A. Alexander, Michael W. Firmin, Shanna Attai, Courtney B. Johnson, Ruth L. Firmin, and Kena E. Mena. 2011. "Using Personality and Cognitive Ability to Predict Academic Achievement in a Young Adult Sample." Personality and Individual Differences 51(6), 709-14.

Bhagat, Vidya, Charan Kishor Shetty, Rohayah Husain, Khairi Che Mat, Nordin Bin Simbak, Myat Moe Thwe Aung, and San San Oo. 2019. "The Relationship between Big Five Personality Traits and Academic Performance in Medical Students." Research Journal of Pharmacy and Technology 12(9), 4189-96.

Brandt, Naemi D., Clemens M. Lechner, Julia Tetzner, and Beatrice Rammstedt. 2019. "Personality, Cognitive Ability, and Academic Performance: Differential Associations across School Subjects and School Tracks." Journal of Personality.

Cazan, Ana-Maria, and Bianca-Andreea Schiopca. 2014. "Self-Directed Learning, Personality Traits and Academic Achievement." Procedia-Social and Behavioral Sciences 127, 640-44. 
Chandramohan, Pavithra Raj; Dr. V. 2015. "Emotional Intelligence Predicting Academic Achievement among College Students." International Journal of Science and Research (IJSR) 4(3), 1275-78.

Ciorbea, Iulia, and Florentina Pasarica. 2013. "The Study of the Relationship between Personality and Academic Performance." Procedia-Social and Behavioral Sciences 78, 400-404.

Conard, Maureen A. 2006. “Aptitude Is Not Enough: How Personality and Behavior Predict Academic Performance." Journal of Research in Personality 40(3), 339-46.

Demetriou, Andreas, Smaragda Kazi, George Spanoudis, and Nikolaos Makris. 2019. "Predicting School Performance from Cognitive Ability, Self-Representation, and Personality from Primary School to Senior High School.” Intelligence 76, 101381.

Duff, Angus, Elizabeth Boyle, Karen Dunleavy, and John Ferguson. 2004. "The Relationship between Personality, Approach to Learning and Academic Performance." Personality and Individual Differences 36(8), 1907-20.

Dzulkifli, Mariam Adawiah, and Intan Aidura Alias. 2012. "Students of Low Academic Achievement-Their Personality, Mental Abilities and Academic Performance: How Counsellor Can Help." International Journal of Humanities and Social Science 2(23), 220-25.

Entwistle, Noel. 2018. "Predicting Academic Performance at University." Student Learning and Academic Understanding 29-43.

Erfani, Shiva Seyed, and Hoda Mardan. 2017. "The Relationship between Big-Five Personality Traits, English Language Proficiency Scores on IELTS, and Academic Success of Iranian Foreign Students." Theory and Practice in Language Studies 7(11):1046-58.

Furnham, Adrian, Tomas Chamorro-Premuzic, and Fiona McDougall. 2003. "Personality, Cognitive Ability, and Beliefs about Intelligence as Predictors of Academic Performance." Learning and Individual Differences 14(1), 47-64.

Furnham, Adrian, Jeremy Monsen, and Gorkan Ahmetoglu. 2009. “Typical Intellectual Engagement, Big Five Personality Traits, Approaches to Learning and Cognitive Ability Predictors of Academic Performance." British Journal of Educational Psychology 79(4), 769-82.

Galleher, Carolyn, Peter J. Rundquist, David B. Barker, and Wen-Pin Chang. 2012. "Determining Cognitive and Non-Cognitive Predictors of Success on the National Physical Therapy Examination." Internet Journal of Allied Health Sciences and Practice 10(4), 7.

Gatzka, Thomas, and Benedikt Hell. 2018. "Openness and Postsecondary Academic Performance: A Meta-Analysis of Facet-, Aspect-, and Dimension-Level Correlations." Journal of Educational Psychology 110(3), 355. 
Ghazi, Safdar Rehman, Gulap Shahzada, and Saif Ullah. 2013. "Relationship between Students' Personality Traits and Their Academic Achievement in Khyber Pakhtunkhwa, Pakistan." Journal of Educational and Social Research 3(2), 437.

Gilles, Pierre-Yves, and Christine Bailleux. 2001. "Personality Traits and Abilities as Predictors of Academic Achievement." European Journal of Psychology of Education $16(1), 3-15$.

Goldberg, Lewis R. 1990. "An Alternative "description of Personality": The Big Five Factor Structure.” Journal of Personality and Social Psychology 59(6), 1216-29.

Goldberg, Lewis R. 1992. "The Development of Markers for the Big-Five Factor Structure." Psychological Assessment 4(1), 26-42.

Hakimi, Soraya, Elaheh Hejazi, and Masoud Gholamali Lavasani. 2011. "The Relationships between Personality Traits and Students' Academic Achievement." Procedia-Social and Behavioral Sciences 29, 836-45.

Hamid, Azhar Adhiem. 2019. "External and Internal Factors Affecting Students' Academic Performance." Basic Education College Magazine For Educational and Humanities Sciences (43), 2098-2115.

Ismail, Ahmed Omer, Ahmad K. Mahmood, and Abdelzahir Abdelmaboud. 2018. "Factors Influencing Academic Performance of Students in Blended and Traditional Domains." International Journal of Emerging Technologies in Learning (IJET) 13(02), $170-87$.

Jensen, Mikael. 2015. "Personality Traits, Learning and Academic Achievements." Journal of Education and Learning 4(4), 91-118.

Kalita, Sima. 2016. "Academic Achievement of High School Students in Relation to Their Emotional Stability.” Journal of Process Management. New Technologies 4(4), $1-4$.

Kashy-Rosenbaum, Gabriela, Oren Kaplan, and Yael Israel-Cohen. 2018. "Predicting Academic Achievement by Class-level Emotions and Perceived Homeroom Teachers' Emotional Support." Psychology in the Schools 55(7), 770-82.

Kholin, Mareike, James A. Meurs, Gerhard Blickle, Andreas Wihler, Christian Ewen, and Tassilo D. Momm. 2016. "Refining the Openness-Performance Relationship: Construct Specificity, Contextualization, Social Skill, and the Combination of Trait Self-and Other-Ratings." Journal of Personality Assessment 98(3), 277-88.

Kirkagac, Senay, and Hüseyin Öz. 2017. "The Role of Big Five Personality Traits in Predicting Prospective EFL Teachers'Academic Achievement." Online Submission 4(4), 317-28.

Komarraju, Meera, and Steven J. Karau. 2005. "The Relationship between the Big Five Personality Traits and Academic Motivation." Personality and Individual Differences 39(3), 557-67. 
Komarraju, Meera, Steven J. Karau, Ronald R. Schmeck, and Alen Avdic. 2011. "The Big Five Personality Traits, Learning Styles, and Academic Achievement.” Personality and Individual Differences 51(4), 472-77.

Köseoglu, Yaman. 2016. "To What Extent Can the Big Five and Learning Styles Predict Academic Achievement." Journal of Education and Practice 7(30), 43-51.

Kotomina, O. V. 2017. "Investigation on the Relationship between Emotional Intelligence and Academic Achievement of University Students." Obrazovaniye $i$ Nauka= The Education and Science Journal, 91-105.

Lee, Jihyun, and Lazar Stankov. 2018. "Non-Cognitive Predictors of Academic Achievement: Evidence from TIMSS and PISA." Learning and Individual Differences $65,50-64$.

Lee, Young Ju, and Yoojung Chae. 2013. "Cognitive Ability and Personality as Predictors of Academic Performance: Science Gifted Students." Journal of Gifted/Talented Education 23(4), 523-35.

Leeson, Peter, Joseph Ciarrochi, and Patrick C. L. Heaven. 2008. "Cognitive Ability, Personality, and Academic Performance in Adolescence." Personality and Individual Differences 45(7), 630-35.

Leighton, Jacqueline P., Qi Guo, Man-Wai Chu, and Wei Tang. 2018. "A Pedagogical Alliance for Academic Achievement: Socio-Emotional Effects on Assessment Outcomes." Educational Assessment 23(1), 1-23.

Lim, P. S., and L. Y. Melissa Ng Abdullah. 2012. "Relationship between Big-Five Personality Domains and Students' Academic Achievement." Pertanika Journal of Social Sciences \& Humanities 20(4).

Lounsbury, John W., Eric Sundstrom, James L. Loveland, and Lucy W. Gibson. 2003. "Broad versus Narrow Personality Traits in Predicting Academic Performance of Adolescents." Learning and Individual Differences 14(1), 65-75.

Loveland, James Michael. 2004. "Cognitive Ability, Big Five, and Narrow Personality Traits in the Prediction of Academic Performance."

McCrae, Robert R., and Paul T. Costa Jr. 2008. "The Five-Factor Theory of Personality."

Meyer, Jennifer, Johanna Fleckenstein, Jan Retelsdorf, and Olaf Köller. 2019. “The Relationship of Personality Traits and Different Measures of Domain-Specific Achievement in Upper Secondary Education." Learning and Individual Differences 69, $45-59$.

Mihaela, Păişi Lăzărescu. 2015. "Psychological Factors of Academic Success." Procedia-Social and Behavioral Sciences 180, 1632-37. 
Molaei, Akbar. 2016. "The Impact of Conscientiousness Personality Trait on Language Learning Strategy Application in EFL Context." European Online Journal of Natural and Social Sciences: Proceedings 2(2s), pp-668.

Moldasheva, Gulnara, and Monowar Mahmood. 2014. "Personality, Learning Strategies, and Academic Performance.” Education+ Training.

Morales-Vives, Fabia, Elisa Camps, and Jorge Manuel Dueñas. 2020. "Predicting Academic Achievement in Adolescents: The Role of Maturity, Intelligence and Personality." Psicothema 32(1), 84-91.

Nighute, Sunita, and S. K. Sadawarte. 2014. "Relationship between Big Five Personality Traits and Academic Performance in Medical Students." J of Evol Med Dent Sci 3(17).

Noftle, Erik E., and Richard W. Robins. 2007. "Personality Predictors of Academic Outcomes: Big Five Correlates of GPA and SAT Scores." Journal of Personality and Social Psychology 93(1), 116.

Novikova, Irina A., and Alexandra A. Vorobyeva. 2017. "Big Five Factors and Academic Achievement in Russian Students.” Psychology in Russia 10(4), 95.

O’Connor, Melissa C., and Sampo V. Paunonen. 2007. "Big Five Personality Predictors of Post-Secondary Academic Performance." Personality and Individual Differences 43(5), 971-90.

Paunonen, Sampo V, and Michael C. Ashton. 2001. "Big Five Predictors of Academic Achievement." Journal of Research in Personality 35(1), 78-90.

Pulido-Acosta, Federico, and Francisco Herrera-Clavero. 2019. "Predicting Children's Academic Achievement through Emotional Intelligence." Psicologia Educativa 25(1), 23-30.

De Raad, Boele, and Boris Mlačić. 2015. "Big Five Factor Model, Theory and Structure.” International Encyclopedia of the Social \& Behavioral Sciences 2.

De Raad, Boele, and Boris Mlačić. 2017. "The Lexical Foundation of the Big Five Factor Model." The Oxford Handbook of the Five Factor Model, 191-216.

Ramesh, P., K. M. Reddy, R. V. S. Rao, A. Dhandapani, G. Samba Siva, and A. Ramakrishna. 2017. "Academic Achievement and Personality Traits of Faculty Members of Indian Agricultural Universities: Their Effect on Teaching and Research Performance." The Journal of Agricultural Education and Extension 23(1), 79-94.

Raza, Syed Ali, and Nida Shah. 2017. "Influence of the Big Five Personality Traits on Academic Motivation among Higher Education Students: Evidence from Developing Nation.”

Razia, B., and Nabi Ahmad. 2017. "Emotional Intelligence and Socio-Economic Status as the Determinants of Academic Achievement among Adolescents." International Journal of Education and Psychological Research (IJEPR) Volume 6, 2-137. 
Ridgell, Susan D., and John W. Lounsbury. 2004. "Predicting Academic Success: General Intelligence," Big Five" Personality Traits, and Work Drive." College Student Journal 38(4), 607-19.

Rosito, Asina Christina. 2018. "Eksplorasi Tipe Kepribadian Big Five Personality Traits Dan Pengaruhnya Terhadap Prestasi Akademik." Jurnal Psikologi Pendidikan Dan Konseling: Jurnal Kajian Psikologi Pendidikan Dan Bimbingan Konseling 4(1), 6-13.

Shokri, O., P. Kadivar, Z. Naghsh, Z. Ghanai, Z. Daneshvarpour, and Molaei, M. 2007. "Personality Traits, Academic Stress, and Academic Performance."

Sorić, Izabela, Zvjezdan Penezić, and Irena Burić. 2017. "The Big Five Personality Traits, Goal Orientations, and Academic Achievement." Learning and Individual Differences 54, 126-34.

Tan, Chee-Seng, Xiao-Shan Lau, Yian-Thin Kung, and Renu A/L Kailsan. 2019. "Openness to Experience Enhances Creativity: The Mediating Role of Intrinsic Motivation and the Creative Process Engagement." The Journal of Creative Behavior 53(1), 109-19.

Varadwaj, Keka. 2017. "Mediation of Academic Self-Concept between Big Five Personality and Academic Performance." IOSR Journal Of Humanities And Social Science (IOSR-JHSS 22(8), 29-34.

Vedel, Anna, and Arthur E. Poropat. 2017. "Personality and Academic Performance." Encyclopedia of Personality and Individual Differences 1-9.

Wang, J. Y., M. C. Wang, and X. Y. Dai. 2011. "Intelligence and Personality Predict Academic Achievement: The 'Big Five' Perspective." Chinese Journal of Clinical Psychology 19(6), 824-26.

Zahed-Babelan, Adel, and Mahdi Moenikia. 2010. "The Role of Emotional Intelligence in Predicting Students' Academic Achievement in Distance Education System." Procedia-Social and Behavioral Sciences 2(2), 1158-63.

Zupančič, Maja, and Tina Kavčič. 2011. "Predicting Early Academic Achievement: The Role of Higher-versus Lower-Order Personality Traits.” Psihologija 44(4), 295-306. 